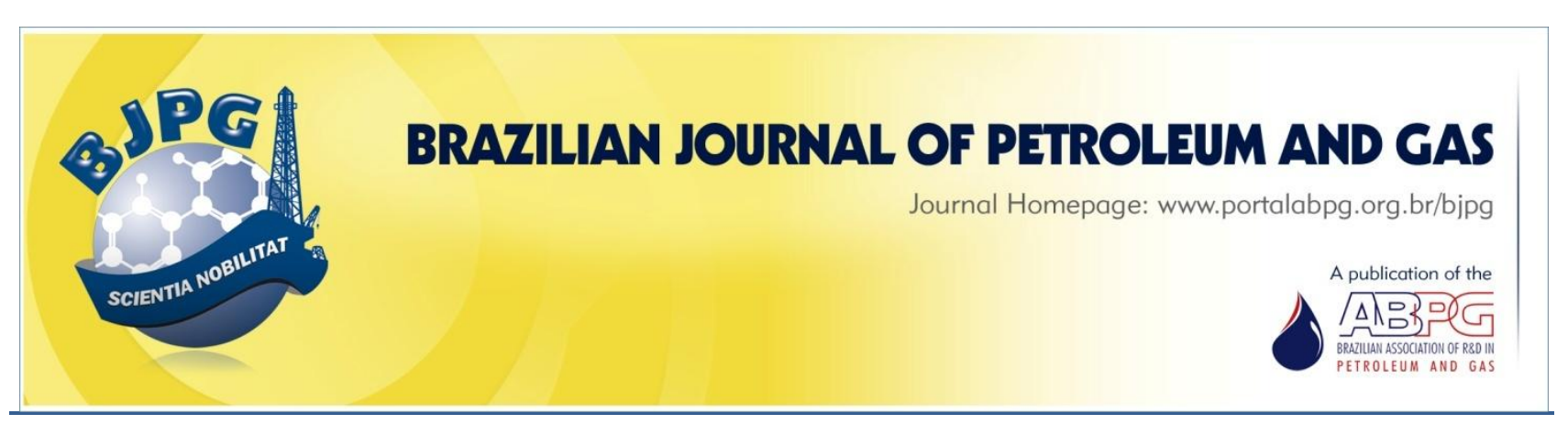

\title{
POLYMER FLOODING IN A HIGH SALINITY HEAVY-OIL RESERVOIR
}

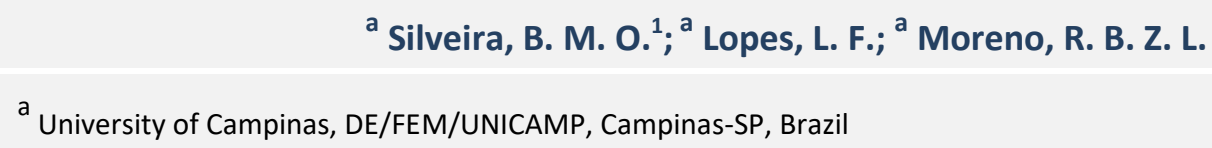

${ }^{a}$ Silveira, B. M. O. ${ }^{1}{ }^{a}$ Lopes, L. F.; ${ }^{a}$ Moreno, R. B. Z. L.

a University of Campinas, DE/FEM/UNICAMP, Campinas-SP, Brazil

Received: 29.10.2017 / Revised: 22.01.2018 / Accepted: 29.01.2018 / Published on line: 16.04.2018

\begin{abstract}
This work aims to present a methodology to evaluate polymer flooding and compare the results with the conventional waterflooding for a target heavy oil reservoir. The dead oil and produced water (SPW) (104 $800 \mathrm{ppm}$ of total solids dissolved) were prepared to represent the reservoir fluids at test conditions $\left(60^{\circ} \mathrm{C}\right)$. SPW was the water source to make and determine the polymer concentration (HPAM-ATBS) to get the target viscosity for the injection fluid $\left(10 \mathrm{mPa} \mathrm{s}\right.$ at $\left.7.8 \mathrm{~s}^{-1}\right)$. Botucatu sandstone samples represented the reservoir formation. We verified the thickness of the polymer solution after flow throughout the rock sample and confirmed higher value than that for injected SPW. Polymer flooding led to the breakthrough delay, shifted the fractional flow to the right, anticipated oil production, and incremented oil recovery. Under the tested conditions, the maximum contribution of polymer flooding occurred up to $70 \%$ of water cut.
\end{abstract}

\section{KEYWORDS}

enhanced oil recovery; polymer flooding; waterflooding; heavy oil; reservoir conditions

\footnotetext{
${ }^{1}$ To whom all correspondence should be addressed.

Address: University of Campinas, DE/FEM/UNICAMP, Rua Mendeleyev, 200, Cidade Universitária "Zeferino Vaz" Barão Geraldo, Campinas-SP, Brazil

ZIP Code: 13083-860| e-mail: zanoni@dep.fem.unicamp.br

doi:10.5419/bjpg2018-0004
} 


\section{INTRODUCTION}

Once the production from conventional oil fields (light oils) reached its peak and started to decline, heavy oil reservoirs became increasingly attractive to supply global demands for oil (Gao, 2011; Jung et al., 2013).

Heavy oil can refer to the crude that ranges from 10 to $22.3^{\circ} \mathrm{API}$ and is more viscous than $100 \mathrm{mPa} s$ (Gao, 2011; George et al., 2013; Meyer et al., 2007; Santos et al., 2014). Other authors consider this kind of crude oil, with viscosities higher than $50 \mathrm{mPa} . \mathrm{s}$ (Shi et al., 2010). Worldwide resources of heavy oil are estimated to be in the order of 3395 billion barrels of original oil in place (OOIP) (Meyer et al., 2007).

Because the heavy crude oil presents higher viscosity and lower mobility than water, the waterflooding can be inefficient due to the instability originated on the interface of the fluids, known as viscous fingering (Gao, 2011; Shi et al., 2015; Van Meurs \& Van Der Poel, 1958). According to the literature, the unstable front occurs when the mobility ratio ( $\left.\mathrm{M}=k_{\text {wef }} \mu_{\mathrm{o}} / k_{\text {oef }} \mu_{\mathrm{w}}\right)$ is higher than a unit (Gogarty, 1967; Pye, 1964; Sandiford, 1964). The $\mathrm{M}$ formula represents water and oil mobility ratio, where the $k_{w e f}, \mu_{w}, k_{o e f}$ and $\mu_{o}$ are the effective permeabilities and viscosities of water and oil phase respectively.

The consequence of this unstable fluid flow is an inefficient displacement, which can result in a poor sweep efficiency (both areal and vertical), early breakthrough of the injected phase and low recovery factor. Under these conditions, a significant amount of mobile oil remains in the reservoir (Doorwar \& Mohanty, 2011; Kumar et al., 2005; Littman, 1988; Sorbie, 1991; Standnes \& Skjevrak, 2014).

Adding water-soluble polymers to the injection fluid increases the displacing phase viscosity and improves the displacement efficiency, even if not reaching a unit mobility ratio (Chen et al., 2012; Levitt et al., 2013; Ramirez, 1987; Sorbie, 1991). This process constitutes an enhanced oil recovery (EOR) method classified as a chemical method. Adding synthetic polymers, such as partially hydrolyzed polyacrylamides (HPAM), leads to an increase in fluid viscosity and a decrease in permeability to the water phase due to polymer adsorption on the rock's surface. As a consequence of these processes, M improves (Lake, 1989; Sorbie, 1991; Sydansk \& Seright, 2007).

Moreover, by reducing $M$, the fractional water flow $(f w)$ also reduces, i.e., for a given value of $f w$, the water saturation is higher for polymer flooding than for waterflooding (Abidin et al., 2012; Lake, 1989; Sorbie, 1991).

There is no consensus in the literature regarding residual oil saturation (Sor) reduction due to polymer flooding (Hou et al., 2009; Sorbie, 1991; Wei et al., 2014). Some authors attribute incremental oil recovered by polymer flooding to the viscoelastic properties of the polymer solution. For them, the elastic modulus $\left(G^{\prime}\right)$ can improve the microscopic displacement (Hou et al., 2009; Wang et al., 2011; Wei et al., 2014; Zhang et al., 2007; Zhang et al., 2011).

Many researchers study the polyacrylamidebased polymers through rheological evaluations, lab experiments, core floodings, and pilot tests. The preference to use HPAM in EOR method can be related to its availability and relatively low cost compared to polysaccharides (Abidin et al., 2012; Aake, 1989; Morel et al., 2007; Osterloh \& Law, 1998). The polymer concentration usually ranges from 500 to $2500 \mathrm{ppm}$ in field applications (Aluhwal, 2008; Xiaodong \& Jian, 2013).

Polymer flooding efficiency can be evaluated by comparing its results to those obtained by waterflooding. Once the target reservoir passes through the screening criteria, experimental procedures can support polymer application. Rheological evaluations, polymer-rock interactions, and displacement tests can be evaluated under reservoir conditions (Al-Maamari et al., 2016; Jung et al., 2013; Wassmuth et al., 2009).

The enhanced oil recovery by polymer flooding, in general, uses some variation of polyacrylamide. The benefits and challenges of this method have been addressed by many authors such as Wang and Dong (2007, 2009); Asghari and Nakutnyy (2008); Jung et al. (2013); Mishra et al. (2014); and Al-Maamari et al. (2016).

The potential of tertiary heavy oil recovery ( 1450 $\mathrm{mPa} s$ ) by polymer flooding (HPAM with $18 \times 10^{6}$ $\mathrm{g} / \mathrm{mol}$ ) was investigated in both homogeneous and channeled sand packs $\left(22.5^{\circ} \mathrm{C}\right)$. The results showed 
that a higher permeable flow channel in the porous media significantly reduced tertiary oil recovery. For homogeneous sand packs, results pointed out an upper and lower limit of viscosity (viscosity-sensitive region) that maximizes recovery. This range characterizes itself by an S-shaped curve (recovery factor versus apparent viscosity). When the polymer flooding started earlier, i.e., under higher oil saturation, the S-shaped curve shifted to lower values of the injected fluid viscosity (Wang and Dong, 2007).

The extension of the work previously commented considered homogenous sand packs and different oil viscosities (430, 1108, 1450, 2900, and $5500 \mathrm{mPa} \mathrm{s}$ ). For each oil tested, the authors found optimal range values of effective viscosity of HPAM solution (S-shaped curves). They observed that the viscosity-sensitive region shifted to higher values for more viscous oils. The use of polymer solutions with viscosities higher than the optimum values did not recover a significant amount of oil (Wang and Dong, 2009).

Another work presents an evaluation of secondary recovery by polymer flooding. The authors tested polyacrylamide solutions (500, 1000,5000 , and $10000 \mathrm{ppm}$ ) to displace heavy oil $(1000,1450$, and $8400 \mathrm{mPa}$ ) in sand packs (permeability of 2 and $13 \mathrm{D}$ ). The experimental results indicated that more permeable porous media and lower oil viscosity favor higher oil recovery. Also, the authors verified that the displacement efficiency decreased by increasing flow rate due to the viscous fingering effects (Asghari \& Nakutnyy, 2008).

The secondary water and tertiary polymer flooding to recover heavy oil ( $450 \mathrm{mPa}$ s) were evaluated through laboratory experiments. Both procedures used glass bead pack $137.0 \%$ of porosity and $3.4 \mathrm{D})$ at $25{ }^{\circ} \mathrm{C}$. They prepared the polymer solution with HPAM $\left(\mathrm{A}-132 \mathrm{PH}, 13 \times 10^{6}\right.$ $\mathrm{g} / \mathrm{mol}$ and a hydrolysis degree of $12 \mathrm{~mol} \%$ ) and $3 w t \%$ of $\mathrm{NaCl}$. According to the results presented, polymer flood was more efficient than water flooding, recovering $21.7 \%$ of OOIP (Jung et al., 2013).

To select the polymer concentration, Mishra et al. (2014) considered the evaluations of onephase and two-phase displacement tests in sand pack systems ( $32.5 \%$ of porosity and $0.3 \mathrm{D}$ ) at 45 ${ }^{\circ} \mathrm{C}$. They used HPAM and oil (5120 mPa s) from the Ahmedabad field. The monophasic test results showed that higher polymer concentrations (2000 and $2500 \mathrm{ppm}$ ) promoted higher values of resistance factor (3.6 and 4.4) and residual resistance factor (1.3 and 1.5). They used these polymer concentrations to evaluate the tertiary recovery (a slug of $0.75 \mathrm{PV}$ after $95 \%$ of water cut (Wcut)) followed by a large volume of water flooding. The incremental oil recoveries obtained were $19 \%$ and $21 \%$ for the solutions with 2000 and $2500 \mathrm{ppm}$ respectively (Mishra et al., 2014).

Focusing on heavy oil field (206 $\mathrm{mPa}$ s) at the South of Oman, AL-Maamari et al. (2016) ran some rheology, adsorption, and displacement tests using reservoir cores ( $24.6 \%$ of porosity and $3.3 \mathrm{D}$ ) at 50 ${ }^{\circ} \mathrm{C}$. Their goal was to choose the molecular weight $(\mathrm{Mw})\left(20\right.$ or $\left.26 \times 10^{6} \mathrm{~g} / \mathrm{mol}\right)$ of HPAM for the polymer flooding application. The authors observed a reduction in injectivity when a polymer with higher $\mathrm{Mw}$ was used, representing a problem for the target field. Thus, they discarded the higher molecular weight polymer. The tertiary recovery with the chosen polymer showed an incremental oil recovery of $4.8 \%$ when compared to the results found for waterflooding.

Implementations of polymer flooding in ZS36-1 field located in Bohai Bay - China allowed checking the benefits of this method over water flooding. The target reservoir was characterized by 28 to $35 \%$ porosity, $2.5 \mathrm{D}$ of permeability, oil viscosity of $70 \mathrm{mPa}$.s and temperature around $65^{\circ} \mathrm{C}$. After ten months of polymer injection, the daily oil production of a given producer well increased 3.5 times, and the Wcut was reduced from $95 \%$ to $54 \%$ (Han et al., 2006).

A pilot test in the East Bodo reservoir AlbertaCanada (range of crude viscosity $60-2000 \mathrm{mPa} \mathrm{s}$ ) started in May of 2006 (30.0\% of porosity and 1.9 D), at $23{ }^{\circ} \mathrm{C}$. According to the data reported, researchers underestimated the impact of the presence of dissolved iron content in the water used to prepare the polymer solutions. This element can chemically degrade the polymer, affecting its rheological properties negatively. Thus, the water source was changed to fresh water to reach the target viscosity (Wassmuth et al., 2009).

Also in Bohai Bay - China, the JZW oil field was considered as a good candidate for polymer 
flooding. The target was a reservoir (22.0 - 36.0 \% of porosity and $0.01-5 \mathrm{D})$ with heavy oil $\left(17-22^{\circ} \mathrm{API}\right)$ and temperature of $57^{\circ} \mathrm{C}$. After polymer application (from 2009 to 2011), the data from 10 production wells showed a $22.6 \%$ (average) water cut reduction and $155 \mathrm{Mbbl}$ of incremental oil recovery. The reported data includes a $30 \%$ production rate increase as a consequence of the application of the technique (Xiaodong \& Jian, 2013).

In other heavy oil fields (China, Turkey, and Oman), the implementation of polymer flooding was also successful (Gao, 2011). However, the author highlighted the challenges to keep the polymer viscosity throughout the flood process. The initial thickness can be reduced by around $50 \%$ of the original one due to the salinity effect and mechanical degradation (Gao, 2011).

Under harsh conditions found in the reservoir, such as high temperature and salinity/hardness, the effectiveness of HPAM is severely affected (Nasr-el-din et al., 1991; Mandal; Ojha, 2008; Samanta et al., 2010; Sheng, 2011). Dissolved cations neutralize the negative charges of the polymer chain, resulting in a molecule shrinkage and, thus, a decrease in fluid viscosity (Nasr-el-din et al., 1991; Sheng, 2011; Sorbie, 1991). The temperature effect reduces the intermolecular forces among the polymer chain, promoting a thermal thinning behavior (Mandal; Ojha, 2008; Samanta et al., 2010). Furthermore, high temperatures can introduce more negatives charges to the polymer backbone. That effect occurs due to the conversion of amide groups $\left(\mathrm{CONH}_{2}\right)$ to carboxyl ones $\left(\mathrm{COO}^{-}\right)$, which allows more interaction with cations (Green \& Willhite, 1998; Lake, 1989; Rashidi et al., 2011; Sheng, 2011).

Chemical degradation is another concern. When the iron content $\left(\mathrm{Fe}^{3+}\right)$ reaches a high level, it can crosslink with HPAM forming an insoluble gel. Consequently, pore plugging around the wellbore can occur, decreasing the injectivity (Wassmuth et al., 2009; Sheng, 2011; Seright \& Skjevrak, 2014).

The presence of $\mathrm{Fe}^{+2}$ itself has no drastic effect on the HPAM viscosity loss, however, when it oxidizes into $\mathrm{Fe}^{+3}$, the free radical $\mathrm{O}_{2}{ }^{-}$is produced. $\mathrm{O}_{2}^{-}$reacts with HPAM to produce peroxide and break the HPAM's backbones (Sheng, 2011).
According to the literature, some HPAM, when copolymerized with the sulfonated monomers, displays a higher resistance to salinity and temperature than traditional HPAM. As monomers examples, one can mention the ATBS group or 2-acrylamide-tertbutyl sulfonic acid (Kamal et al., 2013; Lopes et al., 2014; Seright \& Skjevrak, 2014; Silveira et al., 2016; Thomas et al., 2012). HPAM-ATBS also presents higher resistance to oxidation attack by $\mathrm{O}_{2}{ }^{-}, \mathrm{Fe}^{2+}$ and $\mathrm{Fe}^{3+}$ (Seright and Skjevrak, 2014). This kind of polymer can minimize viscosity, viscoelasticity losses, and degradation (Kamal et al., 2013).

This work aims to evaluate secondary polymer flooding for heavy oil recovery using HPAM-ATBS solution prepared with high salinity/hardness synthetic produced water (SPW) and to compare the results with those obtained injecting SPW (waterflooding). The SPW represents the water source available to make the polymer solution. Additionally, core samples with and without iron content are used to evaluate the polymer flooding efficiency at both scenarios. For these purposes, a methodology was developed to perform and compare the results of both methods under the same conditions found in the target oil reservoir, i.e., type of rock, permoporosity, salinity, oil viscosity, and temperature.

\section{MATERIALS AND METHODS}

The methodology was based on the procedures (fluids project, samples selection and preparation, and displacement test) highlighted in the test protocol presented in Figure 1 . The fluids project aims to replicate the oil and brine properties at the reservoir conditions to the laboratory test conditions, as well as to determine polymer concentration to get the target viscosity of the injection fluid. Rock sample selection and preparation are performed to choose the rock samples with similar permoporosity of the reservoir formation. Displacement tests seek to compare the oil recovery by waterflooding and polymer flooding using the same core under reservoir temperature $\left(60^{\circ} \mathrm{C}\right)$, salinity $(104800 \mathrm{ppm}$ of total solids dissolved), and oil viscosity (180 $\mathrm{mPa}$ s). 


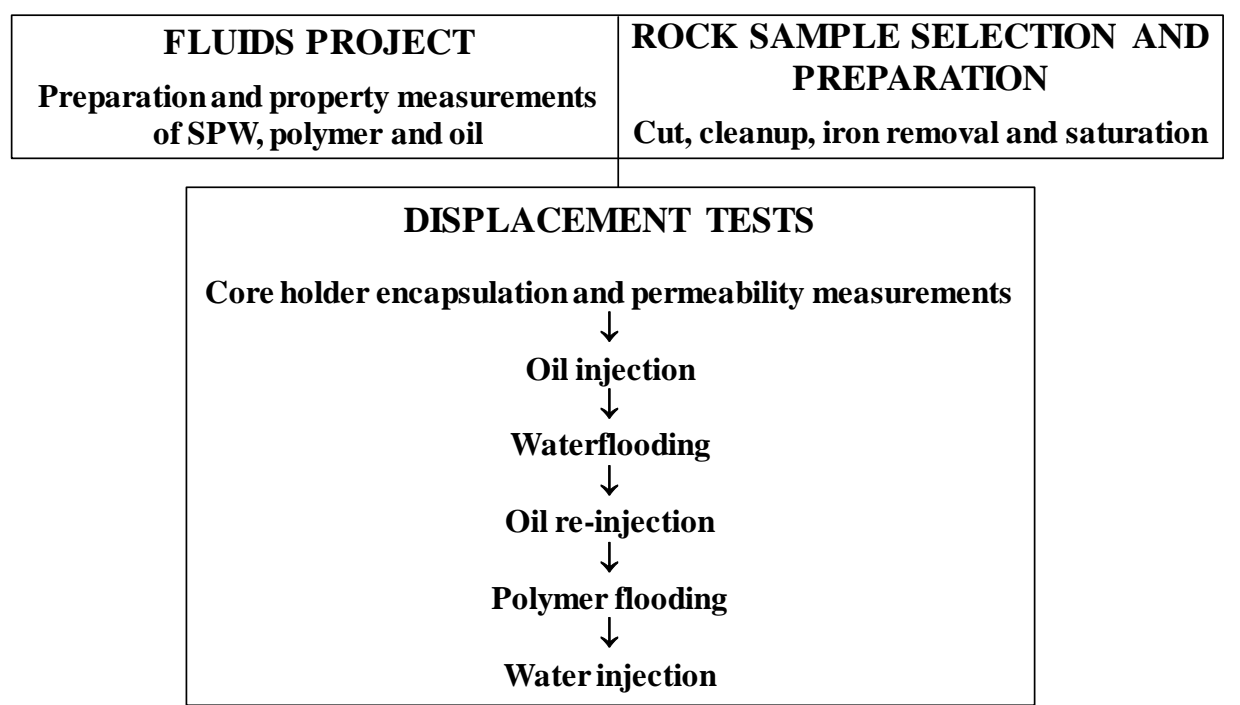

Figure 1. Test protocol.

\subsection{Fluids project}

\subsubsection{Oil}

The oil at reservoir condition had $14^{\circ} \mathrm{API}$ density and $160-180 \mathrm{mPa} s$ viscosity at $60^{\circ} \mathrm{C}$. Under the test temperature $\left(60^{\circ} \mathrm{C}\right)$, the dead oil had $1170 \mathrm{mPa}$.s. The crude was diluted with kerosene (15 wt\%), which is widely applied as a diluent, to obtain the interest viscosity (180 mPa.s) (Asghari \& Nakutnyy, 2008; Gateau et al., 2004; Hart, 2013; Qu et al., 2015).

\subsubsection{Brine}

SPW was prepared with the same composition of the brine found in the target reservoir. This solution was used to saturate rock samples, make the polymer solutions, and perform conventional waterflooding.

The SPW consists of a high salinity and hardness brine including mono and divalent ions with the ionic strength of $1.814 \mathrm{~mol} / \mathrm{L}$ (Silveira et al., 2016). Table 1 shows the ions contained in the SPW and their respective concentrations.

\subsubsection{Polymer solutions}

The polymer used was the Flopaam $5115 \mathrm{SH}$ provided by SNF. This polymer presents a $14-16$ $x 10^{6} \mathrm{~g} / \mathrm{mol}$ of molecular weight $(\mathrm{Mw}), 15 \%$ of hydrolysis degree, $25 \%$ of total anionic charge and $15 \%$ of ATBS (Seright \& Skjevrak, 2014; Silveira et al., 2016).

Preparation procedures followed API-RP-63 (API, 1990). Design procedures and rheological characterization of polymer solutions with HPAMATBS (Flopaam 5115SH) and SPW were performed and presented in a previous work (Silveira et al., 2016).

The required polymer concentration (2000 $\mathrm{ppm}$ ) to get the target viscosity ( $10 \mathrm{cP}$ at $7.8 \mathrm{~s}^{-1}$ ) was obtained by diluting the stock solution with SPW in a beaker and homogenizing it by a magnetic stirrer at a low speed $(120 \mathrm{rpm})$ for 10 minutes. The solutions exhibited homogeneous aspect without insoluble particles (fisheyes).

Table 1. Ion concentrations in the SPW.

\begin{tabular}{ccccccc}
\hline Ions & $\mathrm{Ca}^{2+}$ & $\mathbf{M g}^{2+}$ & $\mathbf{K}^{+}$ & $\mathrm{Na}^{+}$ & $\mathbf{S O}_{4}^{-2}$ & $\mathrm{Cl}^{-}$ \\
\hline Concentration $(\mathrm{ppm})$ & 2726 & 753 & 315 & 34488 & 879 & 59837 \\
\hline
\end{tabular}

Source: Silveira et al. (2016) 


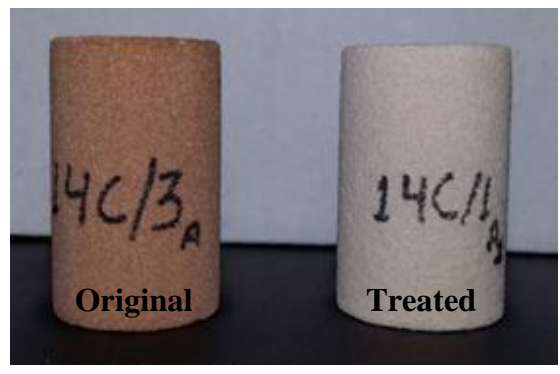

Figure 2. Original and treated Botucatu sandstone samples.

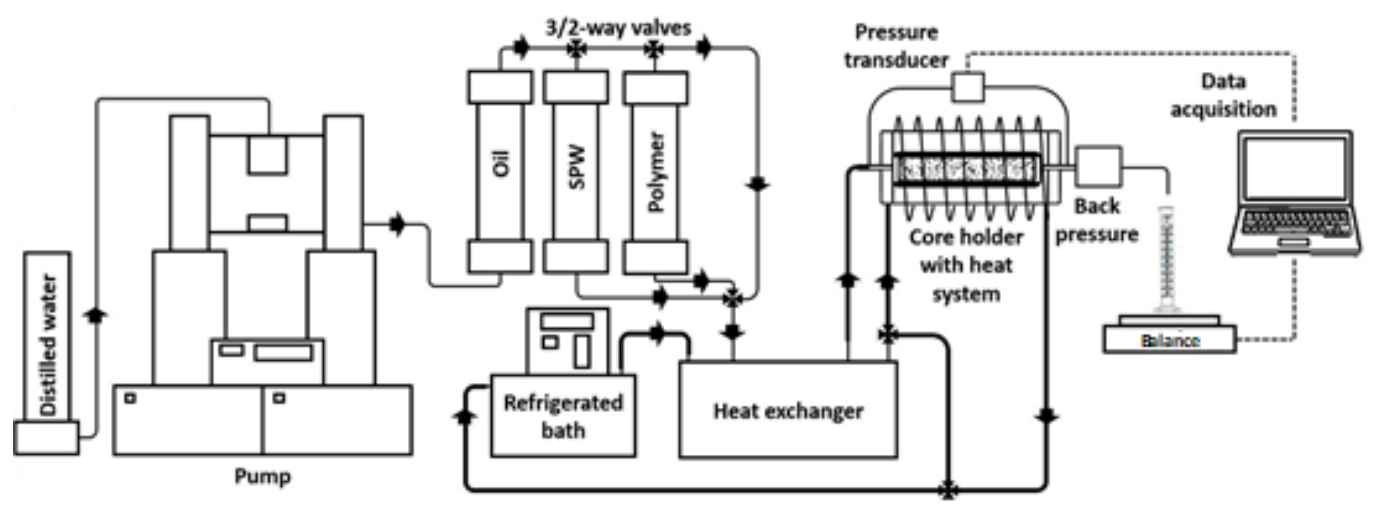

Figure 3. Schematic diagram of experimental apparatus.

\subsection{Rock sample selection and preparation}

Rock samples were selected to represent the permo-porosity properties found in the reservoir

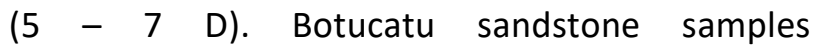
represented the sandstone formation. This surrogate rock originates from an outcrop located in Ribeirão Claro - Paraná State, Brazil. The red coloration of the rock is due to iron oxide content in its constitution (Appoloni et al., 2007; Crósta et al., 2012).

All selected rock samples were cleaned by distillation extraction method (Soxhlet extractor) to remove organic compounds and salts (API, 1998).

According to literature, the chemical degradation of the polymer solution by iron content is a concern. For this reason, this element was removed (by acid treatment) from two rock samples to compare the polymer flooding efficiency with other two original samples, i.e., with iron content.

The plugs were immersed in a container with hydrochloric acid $\left(\mathrm{HCl}_{(\mathrm{aq})}\right)$ for at least three days to remove the iron content from rock samples (Laustre, 2005). $\mathrm{HCl}$ solution reacts with iron oxide
(II or III), producing a metallic salt (iron chloride) and water, as one can see in the equations below.

$\mathrm{FeO}_{(\mathrm{s})}+2 \mathrm{HCl}_{(1)} \rightarrow \mathrm{FeCl}_{2 \text { (aq) }}+\mathrm{H}_{2} \mathrm{O}_{(\text {aq) }}$

$\mathrm{Fe}_{2} \mathrm{O}_{3(\mathrm{~s})}+6 \mathrm{HCl}_{(\mathrm{ll})} \rightarrow 2 \mathrm{FeCl}_{3(\mathrm{aq})}+3 \mathrm{H}_{2} \mathrm{O}_{(\mathrm{aq})}$

After the treatment, the sample was washed with distilled water until reaching a neutral $\mathrm{pH}$. Figure 2 illustrates original and treated samples.

After the commented procedures, the samples were taken to the oven $\left(100{ }^{\circ} \mathrm{C}\right)$ to dry. Then, permo-porosity properties were measured and the samples selected were submitted to a saturation process (with SPW) under vacuum pressure. This procedure aims to ensure that $100 \%$ of porous media is saturated.

\subsection{Displacement tests}

The experimental apparatus is composed of a syringe pump, stainless steel bottles of fluids, heat exchanger, core holder, pressure transducers, back pressure, beakers, scale, and data acquisition system. The oil phase is injected directly into the sample or work as a piston fluid to both SPW and polymer solution. Figure 3 shows the schematic diagram of experimental flooding setup. 


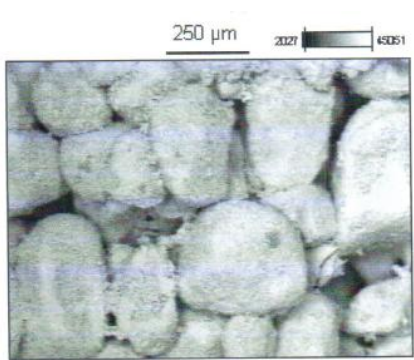

$\mathbf{A}$

Surface image of standard sample

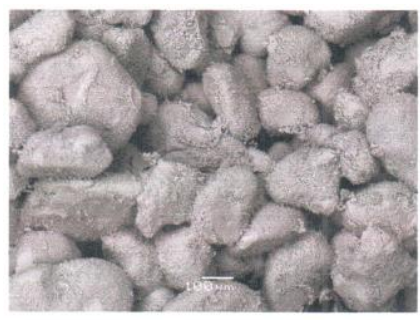

Sample 1

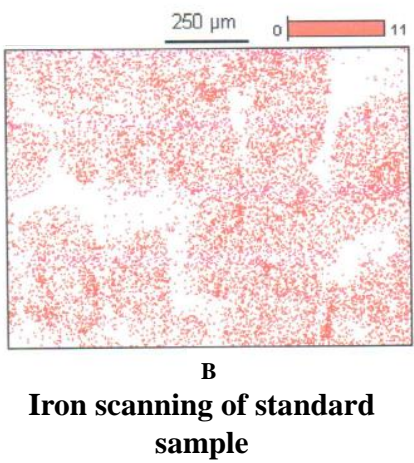

(a)

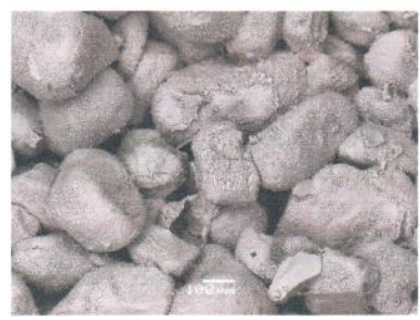

Sample 2

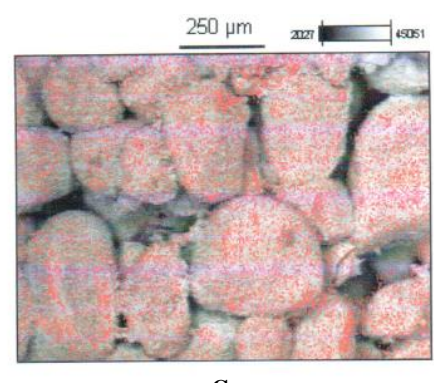

C

Iron distribution

(B overlapping A)

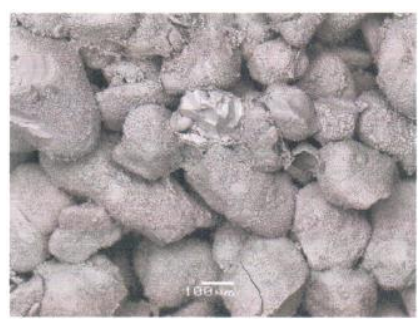

Sample 3

(b)

Figure 4. EDS results for the original sample (a) and three treated samples (b).

Ethylene glycol was diluted with distilled water $(50 \% \mathrm{v} / \mathrm{v})$ as cooling fluid in the refrigerated bath and the heat exchanger devices. Copper coils conducted the heat-transfer between both devices as well as to the core holder. During the tests, differential pressure, produced mass, and volume over the time were recorded.

Saturated samples were encapsulated in a core holder under overburden pressure (900 psi) to ensure one-dimensional flow. At this point, a sequence of fluid injections (in this order: Oil $\rightarrow$ SPW $\rightarrow$ Oil $\rightarrow$ Polymer $\rightarrow$ SPW, as presented in Figure 1) at constant flow rate were run until reaching the steady state conditions at each stage.

These procedures allow the comparison between waterflooding and polymer flooding results at the same core under the connate water saturation, i.e., one rock sample was used for one sequence of injections.

The injection flow rate was $0.7 \mathrm{~cm}^{3} / \mathrm{min}$. It was determined according to the criteria (capillary number, capillary-viscous ratio, and gravity-viscous ratio) to avoid capillary and gravitational effects during two-phase flow (Santos et al., 1997).

\section{RESULTS AND DISCUSSIONS}

\subsection{Iron removal from rock samples}

The procedure applied to remove iron from rock samples using an acid treatment were evaluated and validated by Electron Microscopy Scanning coupled with Spectrometry of X-ray Dispersive Energy (EDS). These techniques allow assessing the iron distribution on the rock surface.

The EDS results of original treated and nontreated samples are presented in Figure 4, which shows the surface scanning of original and treated samples (dimensions of $1 \times 1 \times 0.5 \mathrm{~cm}$ ). Figure 5 shows the EDS spectrum for each treated sample.

According to the EDS results presented in Figure 4 , the presence of iron ions on the rock surface was not identified for samples treated with $\mathrm{HCl}$ and EDS spectra. Figure 5 confirms this result.

These results indicate that the acid treatment removed the iron from the rock samples surfaces. Thus, polymer-flooding procedures in both scenarios were possible, allowing the evaluation of any influence of iron content in the oil recovery efficiency. 


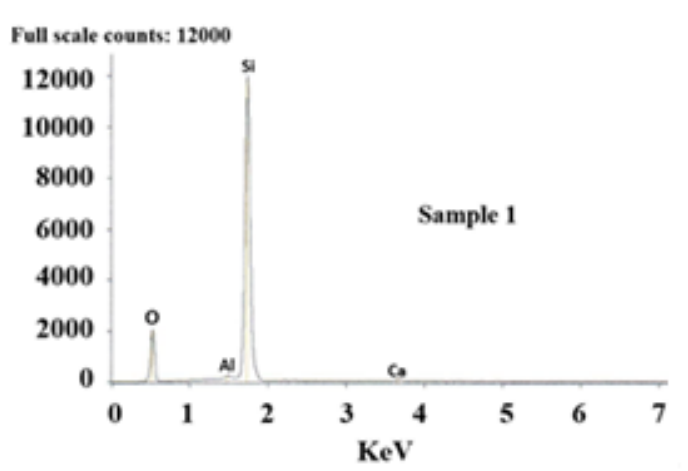

(a)

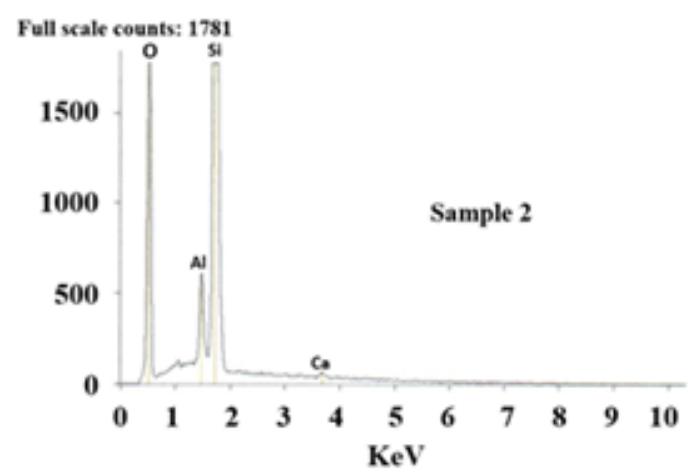

(b)

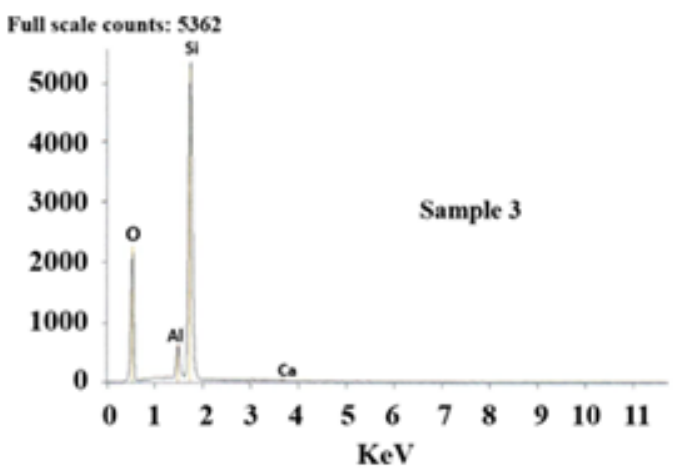

(c)

Figure 5. EDS spectrum of the treated samples: (a) Sample 1, (b) Sample 2, and (c) Sample 3.

\subsection{Fluids properties}

\subsubsection{Viscosity of oil and aqueous phases}

Figure 6 shows the flow curves for the dead oil diluted with kerosene $\left(60^{\circ} \mathrm{C}\right)$, polymer solutions, and the SPW at $23^{\circ} \mathrm{C}$ and $60^{\circ} \mathrm{C}$. All data presented are within of sensor measuring range.

The target oil viscosity ( $180 \mathrm{mPa} \mathrm{s}$ ) was reached to perform the tests at $60{ }^{\circ} \mathrm{C}$ diluting $15 \mathrm{wt} \%$ of kerosene. The temperature effect on SPW viscosity was also measured. The values obtained were similar to brine viscosity values found in the literature, $1.2 \mathrm{mPa}$ s at $23^{\circ} \mathrm{C}$ and $0.6 \mathrm{mPa}$ at $60^{\circ} \mathrm{C}$ (Loahardjo et al., 2010; Wang \& Dong, 2009).

The target viscosity of polymer solution was 10 $\mathrm{mPa} s$ at $7.8 \mathrm{~s}^{-1}$, which can be correlated to the shear rate developed at low flow velocity into the porous medium (Melo et al., 2005). This viscosity was obtained at $23{ }^{\circ} \mathrm{C}$ with $1250 \mathrm{ppm}$ of HPAMATBS.
According to literature, the solution with 1250 ppm of the polymer presents a thermal thinning behavior (Silveira et al., 2016). This behavior indicates that the polymer concentration should be

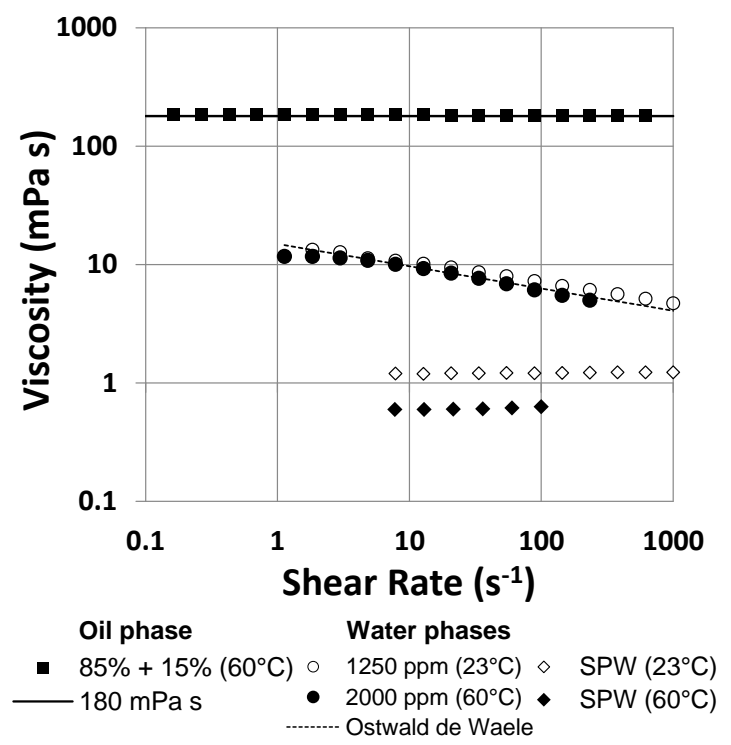

Figure 6. Viscosity vs. Shear rate of oil and aqueous phases. 
Table 2. Fluids properties.

\begin{tabular}{|c|c|c|c|c|}
\hline Parameter/Sample & $\begin{array}{c}A 3 \\
\left(60^{\circ} \mathrm{C}\right)\end{array}$ & $\begin{array}{c}\mathrm{A} 4 \\
\left(60^{\circ} \mathrm{C}\right)\end{array}$ & $\begin{array}{c}A 5 \\
\left(60^{\circ} \mathrm{C}, \mathrm{HCl}\right)\end{array}$ & $\begin{array}{c}A 6 \\
\left(60^{\circ} \mathrm{C}, \mathrm{HCl}\right)\end{array}$ \\
\hline SPW density (g/ml) & 1.07 & 1.06 & 1.07 & 1.07 \\
\hline SPW viscosity (mPa s) & 0.6 & 0.6 & 0.6 & 0.6 \\
\hline SPW pH & 5.3 & 5.1 & 5.7 & 5.4 \\
\hline Oil density (g/ml) & 0.92 & 0.92 & 0.92 & 0.92 \\
\hline Oil viscosity (mPa s) & 180 & 184 & 172 & 166 \\
\hline Polymer density (g/ml) & 1.07 & 1.06 & 1.07 & 1.07 \\
\hline Polymer viscosity (mPa s) at $7.8 \mathrm{~s}^{-1}$ & 9.8 & 9.6 & 9.6 & 10.0 \\
\hline Effective viscosity & 1.56 & 1.98 & 1.23 & 1.40 \\
\hline Polymer pH & 6.0 & 5.3 & 5.4 & 5.5 \\
\hline
\end{tabular}

Table 3. Dimensions and petrophysics properties of rock samples.

\begin{tabular}{|c|c|c|c|c|c|c|c|c|c|c|c|c|c|}
\hline \multirow[b]{2}{*}{ Sample } & \multirow[b]{2}{*}{$\begin{array}{c}\mathrm{L} \\
(\mathrm{cm})\end{array}$} & \multirow[b]{2}{*}{$\begin{array}{c}D \\
(\mathrm{~cm})\end{array}$} & \multirow[b]{2}{*}{$\begin{array}{c}\varphi \\
(\%)\end{array}$} & \multirow[b]{2}{*}{$\begin{array}{c}k \\
(m D)\end{array}$} & \multicolumn{3}{|c|}{ Waterflooding } & \multicolumn{3}{|c|}{ Polymer flooding } & \multicolumn{3}{|c|}{ Water injection } \\
\hline & & & & & Soi & $\begin{array}{c}\Delta \mathrm{P} \\
(\mathrm{psi})\end{array}$ & $\begin{array}{l}k w_{\text {eff }} \\
(m D)\end{array}$ & Soi & $\begin{array}{c}\Delta \mathrm{P} \\
(\mathrm{psi})\end{array}$ & RF & $\begin{array}{c}\Delta P \\
(p s i)\end{array}$ & $\begin{array}{l}k w_{\text {eff }} \\
(m D)\end{array}$ & RRF \\
\hline $\mathrm{A} 3\left(60^{\circ} \mathrm{C}\right)$ & 0.10 & 3.77 & 31.3 & 4714 & 0.756 & 0.69 & 83 & & 1.90 & 2.66 & 0.72 & 80 & 1.04 \\
\hline $\mathrm{A} 4\left(60^{\circ} \mathrm{C}\right)$ & 5.90 & 3.77 & 32.1 & 5366 & 0.728 & 0.28 & 221 & 0.657 & 1.62 & 5.82 & 0.51 & 113 & 1.86 \\
\hline $\mathrm{A} 5\left(60^{\circ} \mathrm{C}, \mathrm{HCl}\right)$ & 6.06 & 3.76 & 33.5 & 5093 & 0.658 & 0.46 & 126 & 0.547 & 1.62 & 3.47 & 0.81 & 72 & 1.74 \\
\hline $\mathrm{A} 6\left(60^{\circ} \mathrm{C}, \mathrm{HCl}\right)$ & 6.89 & 3.77 & 33.8 & 4926 & 0.667 & 0.69 & 99 & 0.617 & 2.22 & 3.22 & 0.99 & 68 & 1.46 \\
\hline
\end{tabular}

$1 \mathrm{psi}=6894.8 \mathrm{~Pa}$

increased to reach the target viscosity at the test temperature $\left(60^{\circ} \mathrm{C}\right)$. Thus, some solutions with higher polymer concentration were prepared and analyzed by flow curves experiments (under the same range of shear rate, but at $60^{\circ} \mathrm{C}$ ).

The results pointed out that the polymer concentration required to reach the target viscosity was $2000 \mathrm{ppm}$. The flow curve of this concentration was presented in Figure 6 . Furthermore, both polymer solutions $(1250 \mathrm{ppm}$ and $2000 \mathrm{ppm}$ ) were characterized as pseudoplastic fluids with shear thinning behavior. Ostwald-de Waele model $\left(\tau=K \dot{\gamma}^{n}\right)$ with a flow behavior exponent $(\mathrm{n})$ of 0.812 and a flow consistency index (K) of 0.015 Pa.s fitted the data.

Table 2 summarizes the properties of the fluids used in each displacement test. The effective viscosity of polymer solution $\left(\mu_{\text {eff }}\right)$, i.e., terminal viscosity at steady state, was calculated considering the effective permeability to polymer solution as equal to the permeability to the SPW obtained in the last water injection. Thus, the effective viscosity of the polymer can be determined as follows $\mu_{\text {eff }}=$ RF/RRF. $\mu_{\text {SPW }}$ (Castagno et al., 1987;
Wang \& Dong, 2009; Shi et al., 2015). The RF (Resistance Factor) and RRF (Residual Resistance Factor) values are available in Table 3.

\subsection{Displacement tests}

The heavy oil recovery by waterflooding (W.F) and polymer flooding (P.F) were performed under the same condition, i.e., rock samples saturated with oil at connate water saturation (Swi). The tests were run in duplicate with two original ( $\mathrm{A} 3$ and $\mathrm{A} 4$ ) and two treated ( $A 5$ and $A 6)$ sandstone samples. These samples were selected to meet the permoporosity properties of a target reservoir.

Table 3 shows sample dimensions and petrophysics properties, initial oil saturation (Soi) before the start of each recovery procedure, stabilized differential pressure $(\Delta \mathrm{P})$, effective permeability at residual oil saturation $\left(k w_{\text {eff }}\right), R F$, and RRF.

Figure 7 shows the recovery factors (Rec. F) and pressure history $(\Delta P)$ versus injected pore volume (PV) obtained during water and polymer flooding. Table 4 summarizes the main results achieved during displacement tests. 

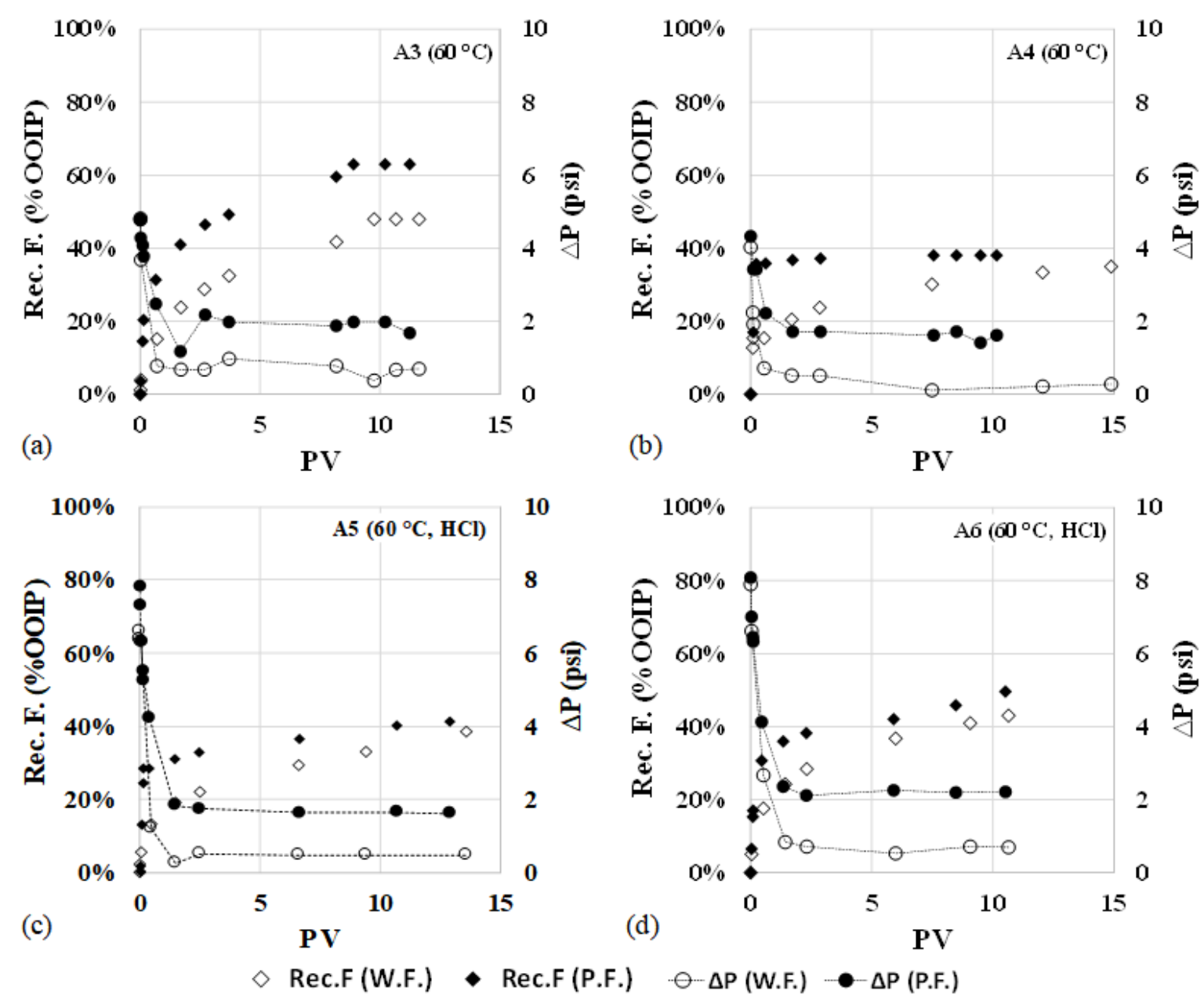

Figure 7. Recovery factor and pressure history for both waterflooding and polymer flooding: (a) and (b) are original samples; (c) and (d) are treated samples.

Comparing the $\Delta \mathrm{P}$ values, the plateaus obtained during the polymer injections reached pressure values higher than those obtained through the conventional oil recovery. These results confirm the higher resistance of polymer solution to flow through the porous media. Table 3 includes the correspondent values for RF.

Furthermore, the stabilized $\Delta \mathrm{P}$ values during the water injection after polymer flooding were higher than that $\Delta \mathrm{P}$ related to waterflooding (water injection before polymer). Thus, polymer flow through the porous medium reduced water permeability. This phenomenon created an incremental resistance to the water flow, which was confirmed by RRF values presented in Table 3.

According to Rec. F data, polymer flooding caused anticipation of oil production and a final incremental recovery. The polymer flooding curves

Table 4. Results of both recovery methods.

\begin{tabular}{|c|c|c|c|c|c|c|c|c|c|c|c|c|}
\hline \multirow{3}{*}{ Sample } & \multicolumn{6}{|c|}{ Waterflooding } & \multicolumn{6}{|c|}{ Polymer flooding } \\
\hline & \multirow[b]{2}{*}{ M } & \multirow[b]{2}{*}{$1^{*}$} & \multicolumn{2}{|c|}{ BT } & \multicolumn{2}{|c|}{ Total } & \multirow[b]{2}{*}{$\mathbf{M}$} & \multirow[b]{2}{*}{$1^{*}$} & \multicolumn{2}{|c|}{ BT } & \multicolumn{2}{|c|}{ Total } \\
\hline & & & PV & $\begin{array}{c}\text { Rec.F } \\
(\%)\end{array}$ & PV & $\begin{array}{c}\text { Rec.F } \\
\text { (\%) }\end{array}$ & & & PV & $\begin{array}{c}\text { Rec.F } \\
(\%)\end{array}$ & PV & $\begin{array}{c}\text { Rec.F } \\
\text { (\%) }\end{array}$ \\
\hline $\mathrm{A} 3\left(60^{\circ} \mathrm{C}\right)$ & 6.2 & 1.02 & 0.03 & 4.0 & 11.63 & 48.0 & 2.6 & 0.38 & 0.14 & 20.4 & 11.24 & 63.0 \\
\hline $\mathrm{A} 4\left(60^{\circ} \mathrm{C}\right)$ & 14.5 & 2.58 & 0.11 & 15.4 & 14.89 & 35.0 & 2.7 & 0.44 & 0.23 & 35.7 & 10.15 & 38.0 \\
\hline A5 $\left(60^{\circ} \mathrm{C}, \mathrm{HCl}\right)$ & 13.2 & 1.52 & 0.04 & 5.6 & 13.61 & 38.6 & 4.4 & 0.44 & 0.15 & 28.2 & 12.93 & 41.2 \\
\hline $\mathrm{A} 6\left(60^{\circ} \mathrm{C}, \mathrm{HCl}\right)$ & 9.2 & 1.03 & 0.03 & 5.1 & 10.65 & 43.0 & 3.1 & 0.32 & 0.11 & 17.0 & 10.51 & 49.6 \\
\hline
\end{tabular}

${ }^{*}$ Injectivity $(\mathrm{I}=\mathrm{q} / \Delta \mathrm{P})$ 


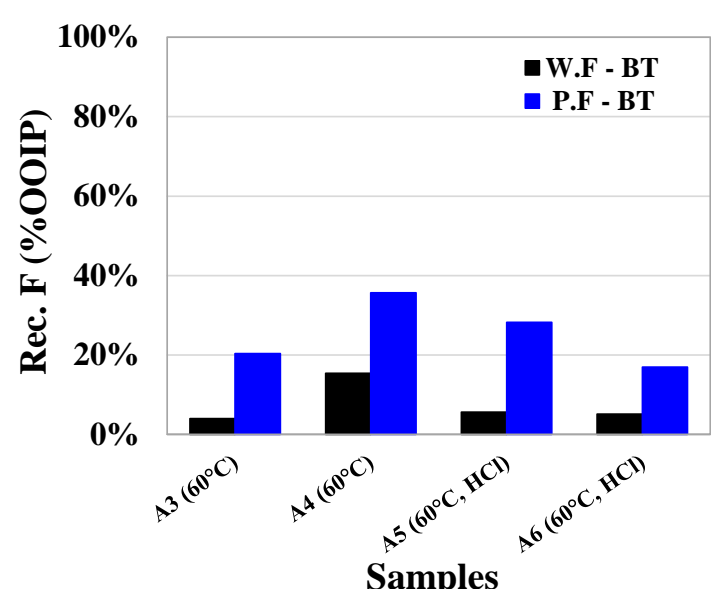

(a)

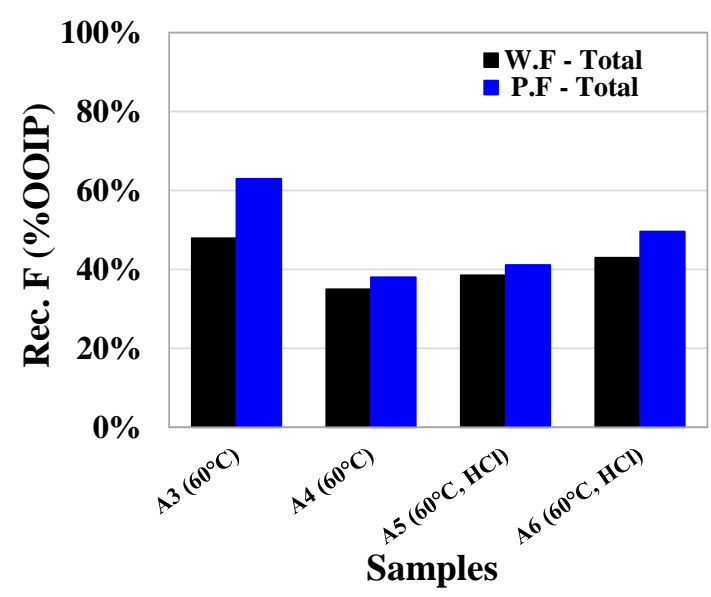

(b)

Figure 8. Recovery factor for each test: (a) At breakthrough (BT) of the injected phase, and (b) At the end of waterflooding (W.F.) and polymer flooding (P.F.).

shifted upwards and to the left, related to those obtained by waterflooding. Table 4 presents the improvement of mobility ratio due to the addition of polymer in the displacing fluid. This phenomenon enhances the displacement efficiency and consequently increases the oil production. Similar results were reported in other work, which attributed this behavior to the mobility ratio reduction by polymer flooding (Wassmuth et al., 2007).

Figure 8 shows the recovery factors obtained at the breakthrough time (BT) of the injected fluid and the end of injection for each test. Three points are considered for the end of each procedure: no oil production, water cut over $95 \%$ and a constant pressure drop $\Delta \mathrm{P}$.

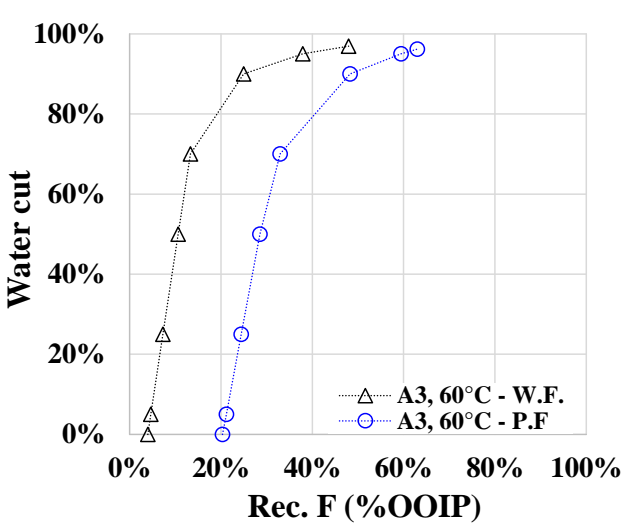

(a)

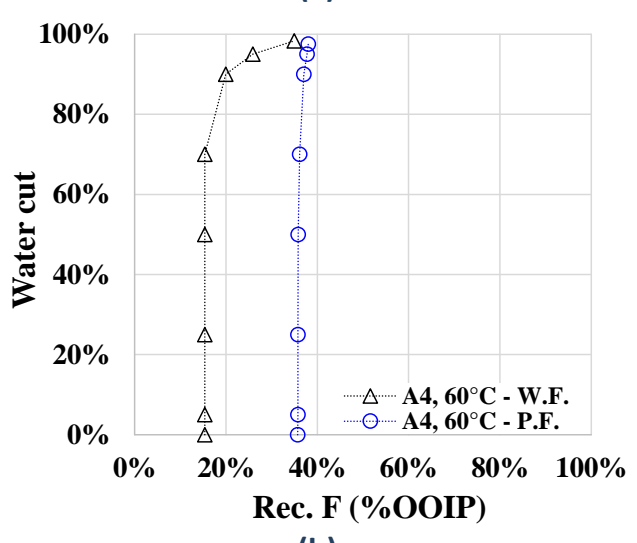

(b)

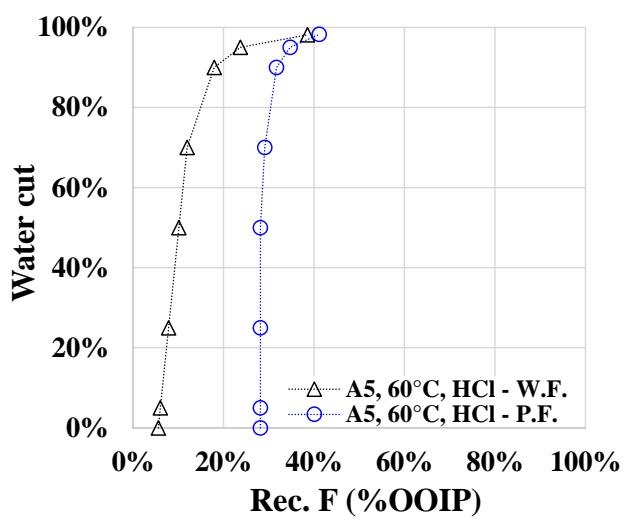

(c)

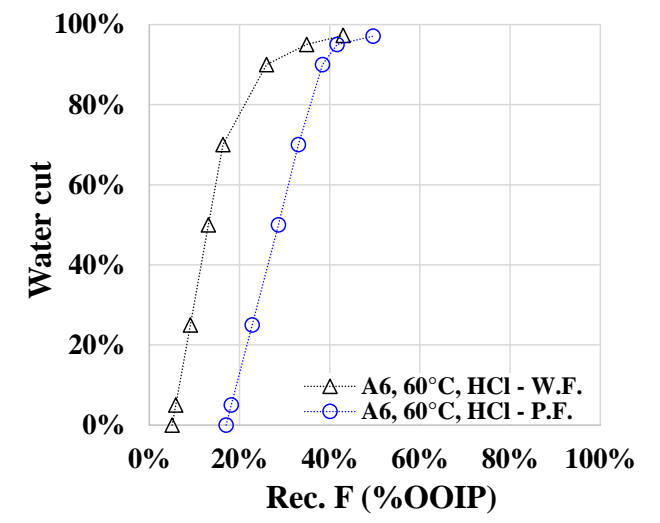

(d)

Figure 9. Water cut vs. Rec. F for both recovery methods: (a) and (b) are original samples, (c) and (d) are treated samples. 


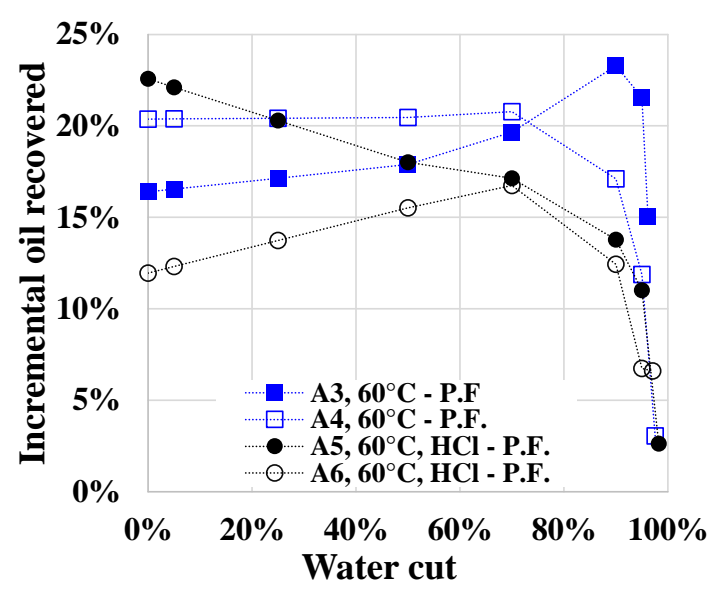

Figure 10. Incremental oil recovered vs. water cut by polymer flooding for each test.

The incremental oil recovered by the polymer flooding was higher at the BT $(16.4 \%, 20.3 \%$, $22.6 \%$, and $11.9 \%)$ than at the end of procedure $(15.0 \%, 3.0 \%, 2.6 \%$, and $6.6 \%)$ for the samples $A 3$ $\left(60{ }^{\circ} \mathrm{C}\right), \mathrm{A} 4\left(60^{\circ} \mathrm{C}\right), \mathrm{A} 5\left(60^{\circ} \mathrm{C}, \mathrm{HCl}\right)$, and $\mathrm{A} 6\left(60^{\circ} \mathrm{C}\right.$, $\mathrm{HCl}$ ), respectively. The reason of the higher Rec. $\mathrm{F}$ for samples A3 compared to the other ones was not identified, since that all conditions were the same for all displacement tests.

Delays related to the breakthrough instants (in injected PV, Table 4) of the polymer phase compared to the water injection also evidenced the displacement efficiency of polymer flooding. Thus, more displacing fluid remained into the porous media for polymer flooding until the $\mathrm{BT}$, resulting in the oil production anticipation and higher oil production increment until the BT.

The data presented in Figure 9 were calculated for $0 \%$ (BT), 5\%, 25\%, 50\%, 70\%, 90\%, 95\%, and terminal values (higher than $97 \%$ ) of Wcut.

The polymer curve shifted to the right of those obtained by conventional oil recovery. These results support the statement that polymer flooding improves the displacement efficiency. According to these data, for the same Wcut value, polymer flooding led to a higher Rec. $F$ than waterflooding.

Figure 10 presents the incremental oil recovered versus Wcut obtained by polymer flooding for all rock samples tested.

For all the tests (except A5) the increment rate of oil production increased until reached $70 \%$ of
Wcut $(90 \%$ of Wcut for $A 3)$. That indicates an oil recovery maximization by the polymer flooding related to waterflooding. The $70 \%$ of Wcut was reached between 0.74 and 0.99 of the injected pore volume.

In the case of the A5 test, the higher incremental recovery probably occurred before the polymer breakthrough. From these results, one can state the main contribution from polymer flooding occurs during the injection of the first pore volume.

Figure 11 shows the fractional flows of both methods. The data was plotted against normalized water saturation because, during the oil re-injection, the Swi values obtained were different from the first oil saturation (see Table 3).

The injection of polymer solution shifts fractional flows to the right, increasing the average water saturation behind the advance front. That corresponds to a better displacement efficiency for the EOR method applied. These results are related to the $M$ reduction due to the viscosity increase of the injected fluid. In this way, the relative permeability to water reduces as a consequence of the decrease of the fractional water flow (Abidin et al., 2012).

Evaluating the effects of the iron content on polymer flooding, one could not identify evidence related to the detrimental impacts of this element in the method effectiveness for both sandstone samples, i.e., with ( $A 3$ and $A 4$ ), and without ( $A 5$ and $A 6)$ iron. These results indicate that no chemical degradation occurred during polymer flooding under the tested conditions.

The injectivity $(I=q / \Delta P)$ of each flooding method was evaluated to corroborate with the statement above,. As presented in Table 4, the polymer injection decreased the injectivity. However, no discrepancy was observed between the samples with and without iron content. The lower injectivity of the polymer solution is related to $M$ improvements, the higher viscosity of the injected fluid and the polymer retention throughout of porous media, as stated in the literature (Jennings et al., 1971; Carcoana, 1992; Sorbie, 1991; Sydansk \& Seright, 2007). The remaining viscosity of polymer solution at steady state condition was confirmed by the effective viscosity values (see Table 2 ). 


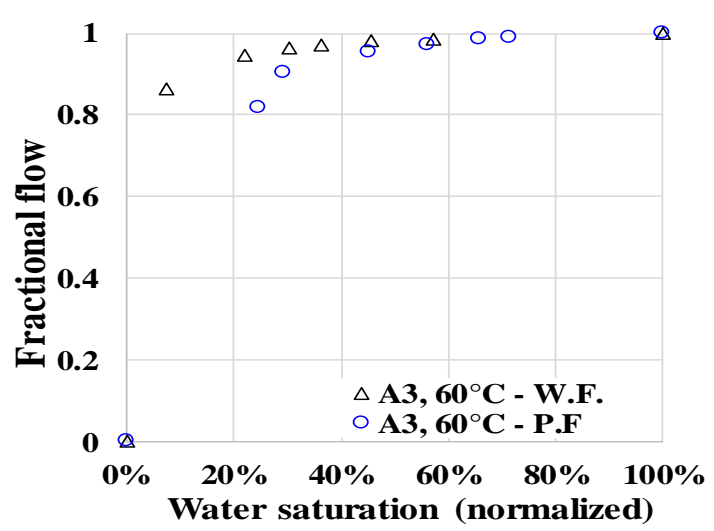

(a)

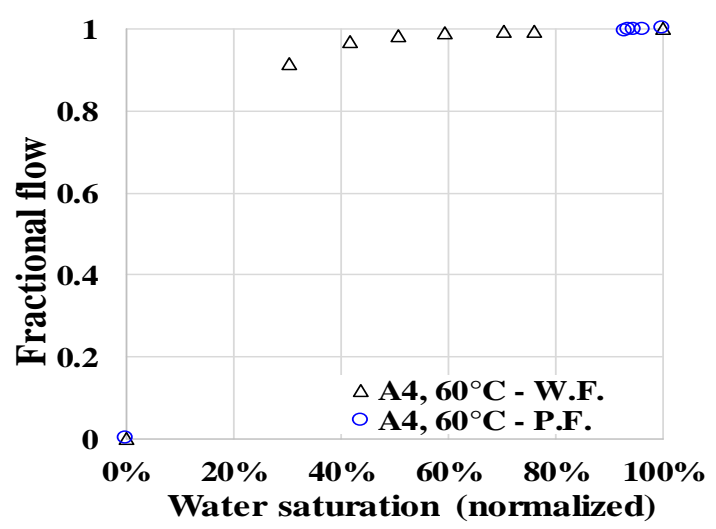

(b)

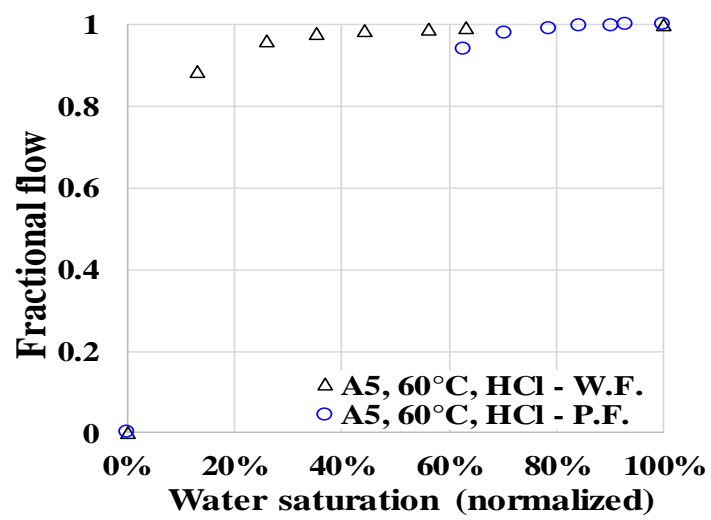

(c)

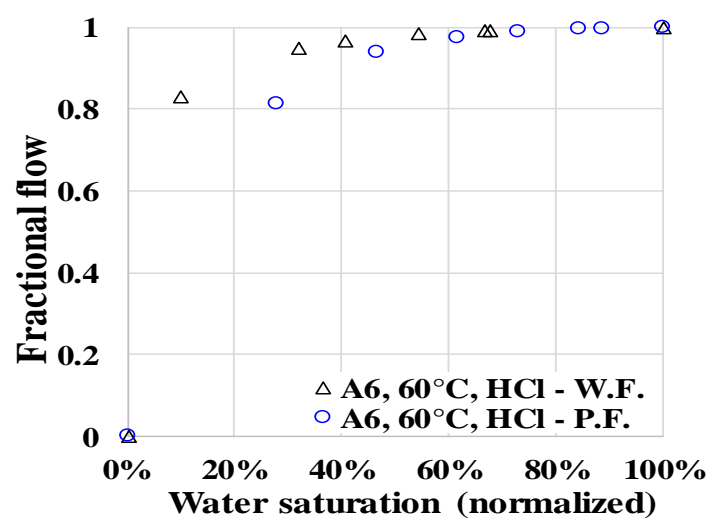

(d)

Figure 11. Fractional flow for both recovery methods: (a) and (b) are original samples, (c) and (d) are treated samples.
According to the results presented in this work the benefits of polymer flooding over waterflooding in the heavy oil recovery are due to the improvement of displacement efficiency. That was attributed to the mobility ratio reduction. Under the tested conditions, any effects of the presence or the absence of iron content in the porous media over the EOR method efficiency could be observed. Also, for the target conditions, the maximum contribution of polymer flooding occurred until $70 \%$ of Wcut, obtained until the first PV.

The main conclusions and contributions of this experimental work are highlighted in the next section.

\section{CONCLUSIONS}

According to the Electron Microscopy Scanning coupled with Spectrometry of X-ray Dispersive Energy results, the acid treatment $(\mathrm{HCl})$ was effective to remove the iron content from rock samples. That allowed the comparison between the core flooding in rock samples with and without iron content.

The iron content in the rock samples did not exhibit any influence on the oil recovery results by waterflooding and polymer flooding, under test conditions.

Considering polymer flooding process for a target-heavy oil reservoir in a laboratory scale, the HPAM-ATBS was successful in maintaining good viscosity behavior in a high-salinity high-hardness synthetic produced water.

The high viscosity of polymer solution improved the mobility ratio when compared to waterflooding. Consequently, the better displacement efficiency of the heavy oil by polymer solution resulted in the delay of the water breakthrough and the shift of the fractional flow to higher values of water saturation. All these factors contributed to the oil production anticipation before the injected fluid breakthrough, and, the increment of the oil recovery. 


\section{ACKNOWLEDGMENTS}

The authors wish to thank the National Agency for Petroleum Natural Gas and Biofuels (ANP), PRHANP, and STATOIL for the financial support.

\section{REFERENCES}

Abidin, A. Z.; Puspassari, T.; Nugroho, W. A. Polymers for Enhanced Oil Recovery Technology. Procedia Chemistry, v. 4, p. 11-16, 2012. https://doi.org/10.1016/i.proche.2012.06.002

Al-Maamari, R. S.; Al-Hashmi, H.; Al-Azri, N.; AlRiyami, O.; Al-Mjeni, R.; Supuis, G.; Zaitoun, A. Laboratory Support of Heavy-Oil Polymer Flood Project. Paper SPE179823 presented in SPE EOR Conference at Oil and Gas West Asia held in Muscat, Oman, 21-23 March, 14p., 2016. https://doi.org/10.2118/179823-MS

Aluhwal, O. K. H. Simulation Study of Improving Oil Recovery by Polymer Flooding in a Malaysian Reservoir. 2008. 185p. Master thesis (Master of Engineering Petroleum) - Faculty of Chemical and Natural Resources Engineering, Universiti Teknologi Malaysia, Malaysia, 2008.

API: American Petroleum Institute. Recommended Practices for Core Analysis, RP40. $2^{\text {nd }} E d$, February, 1998. Washington, DC.

API: American Petroleum Institute. Recommended Practices for Evaluation of Polymers Used in Enhanced Oil Recovery, RP63. $1^{\text {st }}$ June 1990, Washington, DC.

Appoloni, C. R.; Fernandes, C. P.; Rodrigues, C. R. O. X-ray microtomography study of a sandstone reservoir rock. Nuclear Instruments and Methods in Physics Research A, v. 580, n. 1, p. 629-632, 2007. https://doi.org/10.1016/j.nima.2007.05.027

Asghari, K.; Nakutnyy, P. Experimental Results of Polymer Flooding of Heavy Oil Reservoirs. Paper PETSOC-2008-189 presented in Canadian International Petroleum Conference, Calgary, Alberta, 17-19 June. 7p. 2008.

https://doi.org/10.2118/2008-189

Carcoana, A. Applied Enhanced Oil Recovery, Library of Congress Catologing Publication Data, Prentice Hall, Inc, New Jersey, EUA, p. 135-158, 1992.
Castagno, R. E.; Shupe, R. D.; Gregory, M. D. Method for Laboratory and Field Evaluation of a Proposed Polymer Flood. SPE Reservoir Engineering, v. 2, n. 4, p. 452-460, 1987.

https://doi.org/10.2118/13124-PA

Chen, Q.; Wang Y.; Lu Z.; Feng Y. Thermoviscosifying polymer used for enhanced oil recovery: rheological behaviors and core flooding test. Polymer Bulletin, v. 70, n. 2, p. 391-401, 2012. https://doi.org/10.1007/s00289-012-0798-7

Crósta, A. P.; Kazzuo-Vieira, C.; Pitarello, L.; Koeberl, C.; Kenkmann, T. Geology and impact features of Vargeão Dome, southern Brazil. Meteoritics \& Planetary Science, v. 47, n. 1, p. 5171, 2012.

https://doi.org/10.1111/j.1945-5100.2011.01312.x

Doorwar, S.; Mohanty, K. K. Pore-scale fingering during viscous oil displacement. Paper SCA2011-19 presented in International Symposium of the Society of Core Analysts held in Austin, Texas, USA, 18-21 September, 12p. 2011.

Gao, C. H. Scientific research and field applications of polymer flooding in heavy oil recovery. Journal of Petroleum Exploration and Production Technology, v.1, n. 2, p. 65-70, 2011. https://doi.org/10.1007/s13202-011-0014-6

Gateau, P.; Henaut, I.; Barre, L.; Argillier, J. F. Heavy Oil Dilution. Oil \& Gas Science and Technology - Rev. IFP, v. 54, n. 5, p. 503-509, 2004.

George, A. K.; Singh R. N.; Arafin S. Equation of state of crude oil samples. Petroleum \& Environmental Biotechnology, v. 4, n. 6, p.1-4, 2013. https://doi.org/10.4172/2157-7463.1000162

Gogarty, W. B. Mobility control with polymer solutions. Society of Petroleum Engineers Journal, p. 161-175, 1967. https://doi.org/10.2118/1566-B

Green, D. W.; Willhite, G. P. Enhanced Oil Recovery. Richardson, Texas, USA: SPE Textbook Series, v. 6, p. 1-11, 35-72, 100-168, 1998.

Han, M.; Xiang, W.; Zhang, J.; Jiang, W.; Sun. F. SPE 104432. Application of EOR Technology by Means of Polymer Flooding in Bohai Oilfields. Paper SPE 104432 presented in International Oil \& Gas Conference and Exhibition in China, Beijing, China, 5-7 December, 6p. 2006. 
Hart, A. A review of technologies for transporting heavy crude oil and bitumen via pipelines. Journal of Petroleum Exploration and Production Technology, v. 4, n. 3, p. 327-336, 2013. https://doi.org/10.1007/s13202-013-0086-6

Hou, J.; Li, Z.; Zhang, S.; Cao, X.; Du, Q.; Song, X. Computerized Tomography Study of the Microscopic Flow Mechanism of Polymer Flooding. Transport in Porous Media, v. 79, n. 3, p. 407-418, 2009. https://doi.org/10.1007/s11242-008-9330-9

Jennings, R. R.; Rogers, J. H.; West, T. J. Factors Influencing Mobility Control By Polymer Solutions. SPE 2867. Journal of Petroleum Technology, v. 23, n. 03, p.391-401, 1971. https://doi.org/10.2118/2867PA

Jung, J.; C. Zhang, K.; Chon, B. H.; Choi, H, I. Rheology and polymer flooding characteristics of partially hydrolyzed polyacrylamide for enhanced heavy oil recovery. Journal of Applied Polymer Science, v. 127, p. 4833-4839, 2013.

https://doi.org/10.1002/app.38070

Kamal, M. S.; Hussien I.A.; Sultan A.S.; Han M. Rheological Study on ATBS-AM CopolymerSurfactant System in High-Temperature and HighSalinity Environment. Journal of Chemistry, v. 2013, p. 1 - 9, 2013.

https://doi.org/10.1155/2013/801570

Kumar, M.; Hoang, V. T.; Satik, C.; Rojas, D. H. High-Mobility-Ratio Waterflood Performance Prediction: Challenges and New Insights. SPE Reservoir Evaluation \& Engineering, v. 11, n. 1 p. 186-196, 2008. https://doi.org/10.2118/97671-PA

Lake L. W. Enhanced Oil Recovery. New Jersey, USA: Prentice Hall. p. 1-12, 180-230, 314-344, 1989.

Levitt, D.; Jouenne, S.; Bondino, I.; SantanachCarreras, E.; Bourrel, M. Polymer Flooding of Heavy Oil Under Adverse Mobility Conditions. Paper SPE 165267 presented in SPE Enhanced Oil Recovery Conference held in Kuala Lumpur, Malaysia, 2-4 July, 13p. 2013.

https://doi.org/10.2118/165267-MS

Littman, W. Polymer Flooding: Developments in Petroleum Science. Elsevier, Amsterdam, v. 24, p. 14-18, 1988.
Loahardjo, N.; Xie, X.; Morrow N.; R. Oil Recovery by Sequential Waterflooding of MixedWet Sandstone and Limestone. Energy Fuels, v.24, n. 9, p. 5073-5080, 2010.

https://doi.org/10.1021/ef100729b

Lopes, L. F.; Silveira, B. M. O.; Moreno, R. B. Z. L. Rheological Evaluation of HPAM fluids for EOR Applications. International Journal of Engineering \& Technology IJET-IJENS, v. 14, n. 3, p. 35-41, 2014.

Lustre, F.M. Pedra natural clarificada e processo de obtenção. BR n. PI0304389-4, 3 de maio de 2005.

Mandal, A.; Ojha, K. Optimum Formulation of Alkaline-Surfactant-Polymer Systems for Enhanced Oil recovery. Paper SPE 114877 presented in SPE Asia Pacific Oil \& Gas Conference and Exhibition held in Perth, Australia, 20-22 October, 12p. 2008. https://doi.org/10.2118/114877-MS

Melo, M. A.; Holloben, C. R. C.; Silva, I. P. G.; Barros Correia, A.; Sllva, G. A.; Rosa, A. J.; Lins, A. G.; Lima, J. C. Evaluation of Polymer Injection Projects in Brazil. Paper SPE 94898 presented in Latin American and Caribbean Petroleum Engineering Conference, Rio de Janeiro, Brazil, 2023 June, 17p. 2005.

Meyer, R.; Attanasi, E.; Freeman, P. Heavy oil and natural bitumen resources in geological basins of the world. U. S. Geological Survey: open-file report 2007-1084, p.1-36, 2007.

Mishra, S.; Bera, A.; Mandal, A. Effect of polymer adsorption on permeability reduction in enhanced oil recovery. Journal of Petroleum Engineering, v. 2014, p. 1-9, 2014.

https://doi.org/10.1155/2014/395857

Morel, D.; Labasties, A.; Jouenne, S.; Nahas, E. Feasibility Study for EOR by Polymer Injection in Deep Offshore Fields. Paper IPTC 11800 presented in Proceedings of International Petroleum Technology Conference, Dubai, UAE. 46 December, 7p. 2007.

Nasr-El-Din, H. A.; Hawkins. B. F.; Green, K. A. Viscosity Behavior of Alkaline, Surfactant, Polyacrylamide Solutions Used for Enhanced Oil Recovery. Paper SPE 21028 presented in SPE International Symposium on Oilfield Chemistry, held in Anaheim, California, 20-22 February, 14p. 1991. 
Osterloh, W. T.; Law, E. J. Polymer Transport and Rheological Properties for Polymer Flooding in the North Sea Captain Field. Paper SPE 39694 presented in Improved Oil Recovery Symposium held in Tulsa, Oklahoma. 19-22 April, 12p. 1998.

Pye, D. J. Improved secondary recovery by control of water mobility. Journal Petroleum Technology, p.911-916, 1964.

https://doi.org/10.2118/845-PA

Qu, G.; Meng, Y.; Wang, L.; Yu, W. The feasibility study for polymer flooding in heavy oil recovery based on block $X$. Journal of Chemical and Pharmaceutical Research, v. 7, n. 3, p. 2017-2025, 2015.

Ramirez, W. F. Application of Optimal Control Theory to Enhanced Oil Recovery, Developments in Petroleum Science, v. 21, Elsevier. The Netherlands, 1987.

Rashidi, M.; Blokhus, M. A.; Skauge A. Viscosity and Retention of Sulfonated Polyacrylamide Polymers at High Temperature. Journal of Applied Polymer Science, v. 119, n. 6, p. 3623-3629, 2011. https://doi.org/10.1002/app.33056

Samanta, A.; Bera, A.; Ojha, K.; Mandal, A. J. Effects of Alkali, Salts, and Surfactant on Rheological Behavior of Partially Hydrolyzed Polyacrylamide Solutions. Journal of Chemical \& Engineering Data, v. 55, n. 10, p.4315-4322, 2010. https://doi.org/10.1021/je100458a

Sandiford, B. B. Laboratory and Field Studies of Water Floods Using Polymer Solutions to Increase Oil Recoveries. Journal Petroleum Technology, p.917-922, 1964. https://doi.org/10.2118/844-PA

Santos, R. A.; Bedrikovetsky, P.; Hollebeb, C. R. Optimal Design and Planning for Laboratory Coreflood. Paper SPE 39039 presented in the Fifth Latin American and Caribbean Petroleum Engineering Conference and Exhibition, 30 August 3 September, Rio de Janeiro, Brazil, 11p. 1997. https://doi.org/10.2118/39038-MS

Santos, R. G.; Loh. W.; Bannwart, A. C.; Trevisan, $O$. V. An overview of heavy oil properties and its recovery and transportation methods. Brazilian Journal of Chemical, v. 31, n. 3, p. 571-590, 2014. https://doi.org/10.1590/0104-6632.20140313s00001853
Seright, R. S.; Skjevrak, I. Effect of dissolved iron and oxygen on stability of HPAM polymers. Paper SPE 169030 presented at Improved Oil Recovery Symposium, held in Tulsa, Oklahoma, USA, 12-16 April, 12 p. 2014. https://doi.org/10.2118/169030-MS

Sheng, J. J. Modern Chemical Enhanced Oil Recovery - Theory and Practice. Gulf Professional Publishing. Elsevier, p. 51-64; 101-119; 153-164, 2011.

Shi, L.; Ye, Z.; Zhang, Z.; Zhou, C.; Zhu, S.; Guo, Z. Necessity and feasibility of improving the residual resistance factor of polymer flooding in heavy oil reservoirs. Petroleum Science, v. 7, n. 2, p. 251256, 2010. https://doi.org/10.1007/s12182-010-0029-5

Shi, L.; Zhu, S.; Zhang, J.; Wang, S.; Xue, X.; Zhou, W.; Ye, Z. Research into polymer injection timing for Bohai heavy oil reservoirs. Petroleum Science, v. 12, n. 1, p. 129-134, 2015.

https://doi.org/10.1007/s12182-014-0012-7

Silveira, B, M, O; Lopes, L, F; Moreno, R. B. Z. L. Rheological Approach of HPAM Solutions under Harsh Conditions for EOR Applications. International Journal of Engineering \& Technology IJET-IJENS, v. 16, n. 3, p. 1-8, 2016

Sorbie, K. S. Polymer-Improved Oil Recovery. 1a Ed, Boca Raton, Florida: CRC Press, p. 37-79, 128134, 247-260, 312-340, 1991. https://doi.org/10.1007/978-94-011-3044-8

Standnes, D. C.; Skjevrak, I. Literature Review of Implemented Polymer Field Projects. Journal of Petroleum Science and Engineering, v. 122, p. 761-775, 2014.

https://doi.org/10.1016/i.petrol.2014.08.024

Sydansk, R. D.; Seright, R. S. When and Where Relative Permeability Modification Water-Shutoff Treatments can be Successfully Applied. SPE 99371. SPE Production \& Operations, v. 22, n. 2, p. 236247, 2007. https://doi.org/10.2118/99371-PA

Thomas, A.; Gaillard, N.; Favero, C. Some Key Features to Consider When Studying AcrylamideBased Polymers for Chemical Enhanced Oil Recovery. Oil \& Gas Science and Technology - Rev. IFP Energies Nouvelles, v. 67, n. 6, p. 887-902, 2012. 
Van Meurs, P.; Van Der Poel, C. A. A Theoretical Description of Water-Drive Processes Involving Viscous Fingering. Petroleum Transactions, AIME, v. 213, p.103-112, 1958.

Wang, D.; Wang, G.; Xia, H.; Yang, S.; Wu, W. Incremental Recoveries in the Field of Large Scale High Viscous-Elastic Fluid Flooding are Double that of Conventional Polymer Flooding. Paper SPE 146473 presented in SPE Annual Technical Conference and Exhibition, Denver, Colorado, USA, 30 October-2 November. 14p. 2011.

https://doi.org/10.2118/146473-MS

Wang, J.; Dong, M. A. Laboratory Study of Polymer Flooding for Improving Heavy Oil Recovery. Paper PETSOC-2007-178 presented in Canadian International Petroleum Conference held in Calgary, Alberta, 12-14 June. 9p. 2007. https://doi.org/10.2118/2007-178

Wang, J.; Dong, M. Optimum effective viscosity of polymer solution for improving heavy oil recovery. Journal of Petroleum Science and Engineering, v. 67, p.155-159, 2009. https://doi.org/10.1016/j.petrol.2009.05.007

Wassmuth, F. R.; Arnold, W.; Green, K.; Cameron, $\mathrm{N}$. Polymer flood application to improve heavy oil recovery at east bodo. Journal of Canadian Petroleum Technology, v. 48, n. 2 p. 1-7, 2009. https://doi.org/10.2118/09-02-55
Wassmuth, F. R.; Green, K.; Hodgins, L.; Turta, A. T. Polymer Flood Technology for Heavy Oil Recovery. Paper PETSOC-2007-182 presented in Canadian International Petroleum Conference held in Calgary, Alberta, 12-14 June. 12p. 2007. https://doi.org/10.2118/2007-182

Wei, B.; Zerón, R. L.; Rodrigue, D. Oil displacement mechanisms of viscoelastic polymers in enhanced oil recovery (EOR): a review. Journal of Petroleum Exploration and Production Technology, v. 4, n. 2, p. 113-121, 2014. https://doi.org/10.1007/s13202-013-0087-5

Xiaodong, K.; Jian, Z. Offshore Heavy Oil Polymer Flooding Test in JZW Area. Paper SPE 165473 presented in SPE Heavy Oil Conference Canada held in Calgary, Alberta, Canada, 11-13 June, 8p. 2013. https://doi.org/10.2118/165473-MS

Zhang, L.; Yue, X. Mechanism for viscoelastic polymer solution percolating through porous media. Journal of Hydrodynamics, Ser. B, v.19, n.2, p.241-248, 2007. https://doi.org/10.1016/S1001$\underline{6058(07) 60055-9}$

Zhang, Z.; Li, J.; Zhou, J. Microscopic roles of "viscoelasticity" in HPMA polymer flooding for EOR. Transport in Porous Media, v. 86, n. 1, p.199-214, 2011. https://doi.org/10.1007/s11242-010-9616-6 